\title{
Pola Pencarian Informasi Seniman di Ruang Alternatif Seni s.14 Bandung
}

\author{
Chyntia Kartika Sari, Pawit M.Yusup, Wina Erwina \\ Gagas Media Group Published \\ chyntiakartikasari@gmail.com
}

\begin{abstract}
Abstrak - Penelitian ini bertujuan untuk mengetahui Pola Pencarian Informasi Seniman di Ruang Alternatif Seni s.14 Bandung. Ruang lingkup penelitian ini adalah pencarian informasi yang dilakukan oleh seniman ruang alternatif seni s.14. metode yang digunakan adalah studi kasus. Kajian model yang digunakan dalam penelitian ini adalah pencarian informasi professional. Teknik pengumpulan data yang digunakan yaitu observasi, wawancara, studi kepustakaan dan triangulasi. Informan penelitian ini yaitu seniman yang sering terlibat dengan ruang alternatif s.14 dan pengelola sebagai key informan. Hasil penelitian menunjukan bahwa Pola Pencarian Informasioleh seniman ruang alternatif seni s.14 dimulai dengan (1) perencanaan yang didukung tugas serta peran dalam lingkungan serta penyeleksian informasi berdasarkan kebutuhan dan waktu kegunaan informasi, (2) tahap prosedur meliputi kemudahan mendapatkan informasi, kecepatan mendapatkan informasi serta mendukung visualisasi karya lalu (3) sumber literature melalui internet, diskusi dengan ahli serta sumber tercetak. Terdapat upaya yang dilakukan untuk memperoleh sumber - sumber tersebut. Jika terdapat kekurangan informasi, maka seniman akan terus mencari ke sumber - sumber lain yang relevan untuk memenuhi kebutuhan informasinya.
\end{abstract}

Kata kunci : Informasi, Pola Pencarian Informasi, Seniman, Ruang Alternatif Seni, Komunitas, s.14 bandung

Abstract - This study aimed to determine the pattern of This study aimed to determine the pattern of information search by artists of the alternative art space s.14. The scope of this research was the search for information by artist of the alternative art space s.14. the method used is case study. The study's model used in this research was the search for professional information. Data collection techniques used were observation, interview, literature study and triangulation. Informants for this research were artists who were often involved with alternative art space s.14 and the manager was the key informant. The results showed that the pattern of information search by artist of the alternative art space s.14 started with (1) planning supported by task and role in the environment as well as information selection based on the needs and time of the usefulness of information, (2) ease and speed for obtaining information and supporting visualization of previous art works, (3) literary sources on the Internet, printed sources and discussions with experts. Also efforts were made to acquire the sources. If there was a lack of information, then the artist would continue to look for other relevant sources to meet their information needs.

Keywords : information, information behaviour, information pattern, artist, alternative art space, s.14 Bandung community

\section{Pendahuluan}

Seni merupakan bentuk metafisik diri yang dapat divisualisasikan yang selanjutnya menjadi salah satu aktualisasi diri dan luapan bentuk kreativitas dari dalam diri manusia. Seni merupakan komoditas utama bagi seniman. Indonesia sendiri seni berkembang pesat dengan adanya cabang seni yang tidak saja traditional namun berkembang dengan adanya seni modern. Salah satu kota di Indonesia yang berkembang dan melahirkan para seniman hebat yaitu Bandung. Bandung salah satu kota di Indonesia yang mayoritas masyarakatnya aktif dalam bidang seni. Tidak sedikit seniman yang dilahirkan oleh Bandung, sebut saja Harry Roesli, Barli Sasmitawinata, Sunaryo, Srihadi Soedarsono, Popo Iskandar dan masih banyak lagi.

Bahkan pemilihan gubernur Jawa Barat yang sedang dilakukan pada 2013 dari lima pasang calon gubernur Jawa Barat tiga diantara pasangan tersebut menggaet para pekerja seni. Seperti Ahmad Heryawan dengan Dedy Mizwar, Rieke Diah Pitaloka bersama Teten Masduki dan Dede Yusuf dengan Lex Laksamana. Dedy Mizwar, Rieke Diah dan Dede Yusuf dahulu merupakan artis yang tidak sedikit lalu lalang di media baik itu memainkan peran dengan apik ataupun menjadi seorang producer dan director sebuah acara seni. Ini menunjukkan bahwa masyarakat telah menaruh kepercayaan lebih dengan 
memberikan kesempatan kepada calon pemimpin Jawa Barat yang merupakan seseorang berlatar belakang seniman.

Seni memiliki keragaman jenis ada seni rupa, seni musik, seni peran dan juga seni popular. Masyarakat dengan kacamata awam mungkin akan menyamaratakan semua jenis seni dan menyembutnya dengan seniman. Ini merupakan kesalahan mendasar tentang seniman. Dalam bahasa inggris art memiliki arti seni, seseorang yang bergerak dibidang seni rupa disebut artist namun tokoh yang memilih seni popular seperti penyanyi, perfilman disebut aktris. Sehingga artist dan aktris memiliki makna yang berbeda dalam seni.

Namun tidak sedikit beberapa seniman yang berlatar belakang pendidikan formal seni seperti Aming yang mengambil studi mengenai design textile ITB namun ia aktif di bidang entertaintment (seni popular). Indra Herlambang dan Pandji Pragiwaksono juga mengenyam pendidikan formal mengenai seni namun aktif berlalu lalang di seni populer. Terakhir seniman bandung bernama Tisna Sanjaya yang aktif di salah satu program televisi swasta Bandung membawakan acara tentang jawa barat lebih tepatnya budaya sunda, namun ia juga aktif dibidang seni rupa. Tidak sedikit juga yang muncul sebagai kritikus seni, penulis dan kurator sebut saja Jim Supangkat, Rizky A. Zaelani, Aminudin TH Siregar, Agung Wujatnika, Jenong dan Rifky Effendi.

Salah satu instituti favorit di Bandung yaitu Institut Teknologi Bandung dengan program FSRD (Fakultas Seni Rupa Desain) belakangan ini sangat dilirik menurut Radius (2010) dalam kompas mengatakan calon mahasiswa seIndonesia pada tahun 2010 yang mendaftarkan diri berjumlah 4000 orang namun daya tampung yang dapat diterima ITB hanya 125 orang. Sehingga menjadi sebuah kebanggaan jikalau bisa diterima disana. Sehingga menunjukkan bahwa profesi seniman (seni rupa) sedang menjadi perhatian.

Dalam dunia seni rupa pada tahun 2008 hingga 2010 terjadi boom, banyaknya mahasiswa seni rupa yang lebih tertarik menjadi seniman di banding art management. Hal ini mendorong para seniman untuk menvisualisasikan karya lebih banyak agar menunjukkan eksistensi. Namun tidak sedikit juga yang memilih konsen di art management. Visualisasi karya yang tidak mudah dan manajerial seni yang butuh banyak referensi mendukung seniman untuk mencari informasi berdasarkan tugas dan peran ia dalam profesi.

Kebutuhan informasi dapat dikatakan sebagai apa yang sedang dibutuhkan oleh manusia untuk menjawab pertanyaan yang berada di benaknya demi menunjang profesi ataupun kegiatan utama manusia tersebut. Kebutuhan dari tiap orang tiap orang dipengaruhi latar belakang situasi, kognisi dan fisiologis berbeda. Para pegiat seni di Bandung yang diantaranya berlatar belakang sebagai mahasiswa, dosen, kurator memiliki kebutuhan dan cara mencari informasi yang berbeda. Di era informasi seperti saat ini, mencari informasi sudah tidak sulit lagi. Perkembangan teknologi dikuti perbaikan pelayanan pusat informasi memudahkan tiap orang dalam mendapatkan informasi.

Pusat informasi seniman yang formal dibandung berada di wilayah pendidikan seperti FSRD ITB, STSI (Sekolah Tinggi Seni Indonesia), Fakultas Seni UPI adapula FSRD Universitas Maranatha. Selain pusat informasi yang formal di Bandung, pusat seni informal juga berkembang berupa Galeri dan ruang seni alternatif. Menurut Iskandar (2000) Ruang Alternatif merupakan salah satu tempat seniman untuk menunjukkan eksistensi melalui karya ataupun menjadi ruang diskusi bagi seniman dalam bertukar dan share informasi.

Berbeda dengan Galeri yang telah memiliki tim tersendiri dalam mengaudisi seniman dengan standarisasi dari tiap galeri. Menjadi salah satu hambatan bagi seniman untuk memamerkan karya mereka. Berangkat dari kekecewaan itulah pada tahun 2008 dua alumni mahasiswa FSRD ITB yang sekarang menjadi suami istri bernama Herra Pahlasari dan Aminudin TH Siregar mendirikan ruang alternatif seni bagi para seniman muda yang diberi nama s14. Bermula dari ruang tamu yang disulap menjadi ruang pamer dan terus berkembang menjadi lantai satu rumah pribadi mereka yang bertempat di jalan Sosiologi No.14 Komplek Perumahan UNPAD mereka jadikan ruang alternatif dan perpustakaan, dengan harapan seniman muda yang kurang mendapatkan wadah dapat berkumpul dan bisa berbagi informasi satu sama lain. 
Di Bandung sendiri ruang alternatif yang memiliki perpustakaan seperti s14 ada Selasar Sunaryo Art Space yang didirikan oleh Sunaryo berada di dago pakar, namun program yang dimiliki selasar sunaryo art space hanya aktif untuk kalangan seni tersendiri berbeda dengan s14 yang menjadikan ruang alternatif menjadi ruang temu tidak hanya seniman dengan seniman saja tapi juga seniman dengan masyarakat sekitar. Hal ini sejalan dengan tagline s14 yaitu art, life, share.

Perpustakaan s14 yang telah berdiri sejak 2011 memiliki member hingga sampai Januari 2013 jumlah member yang bergabung di Perpustakaan s.14 saat ini sudah mencapai 89 orang, yang berasal dari rekan sejawat dari mba Herra Pahlasari ataupun mahasiswa bang Aminudin yang berprofesi sebagai dosen di FSRD ITB. Namun yang sangat disayangkan dari 89 orang member hanya 15 orang member yang aktif meminjam dan mencari informasi di s.14, jika dipersentasikan hanya $20 \%$ yang memanfaatkan s14 dengan baik. Hal ini sangat disayangkan karena s14 cukup memberikan sarana dengan pusat informasi tambahan berupa perpustakaan dan prasarana dengan program berkala 3 kali dalam setahun. Penulis melihat adanya kejanggalan yang mendorong dilakukannya penelitian mengenai hal terkait diatas. Apabila berpacu pada era informasi seperti saat ini, dimana informasi menjadi asupan utama dalam mendukung keseharian seseorang termasuk juga seniman. Hal inilah yang mendorong penulis untuk mencari tahu seperti apa pencarian informasi yang dilakukan seniman di s.14 untuk menunjang kebutuhan kreativitas dan visualisasi karya bagi mereka.

\section{Kajian Pustaka}

Seniman merupakan salah satu profesi yang menjadikan seni sebagai hal utama dalam kehidupannya. Menurut Supangkat (2013) "Seniman adalah seseorang yang menuangkan kreatifitas di dalam pikirannya dalam bentuk visualisasi karya." Berkaitan dengan seniman Iskandar (2000) mengutarakan terlebih dahulu definisi dari seni, seni merupakan alat pengutaraan konkrit dari suara batin si penciptanya, dalam kesadaran hidup berkelompok. Dari pemaparan konsep seni menurut Iskandar (2000), seniman berarti seseorang yang mampu mengutarakan kesadaran hidup berkelompok secara konkrit dalam bentuk sebuah karya.

Data yang diperoleh melalui wawancara langsung dengan seniman sekaligus kurator seni rupa Indonesia yaitu Jim Supangkat mengacu pada kata "art" dalam bahasa inggris yang artinya adalah seni, memiliki dua bagian pekerja seni yaitu "artist" seseorang yang menvisualisasikan karya dalam bentuk seni rupa dan "the art" seseorang yang menvisualisasikan karya dalam bentuk seni musik dan seni rupa. Sehingga menjadi dua pengucapan hal yang berbeda dari satu profesi yang memiliki line yang sama yaitu seni. Perlu dipahami sebelumnya dalam pandangan barat seniman mengacu kepada seseorang yang menghasilkan karya dalam bentuk seni rupa. Sehingga beberapa orang yang berkarya di bidang seni musik ataupun seni peran tidak dapat disebut sebagai artist atau seniman karena memiliki sebutan yang berbeda. Namun masyarakat Indonesia saat ini terjebak dalam pandangan bahwa semua yang berkarya dalam bidang seni disebut seniman.

Latar belakang seniman yang memiliki profesi dosen ataupun mahasiswa yang tentunya memiliki kebiasaan dalam pencarian informasi yang berbeda. Tujuan mereka dalam mencari informasi juga berbeda sehingga menjadi hal yang lumrah apabila penulis mengambil kesimpulan bahwa meskipun memiliki ketertarikan yang sama motif setiap orang dalam mencari informasi memiliki perbedaan satu sama lain. Seperti juga yang dikemukakan oleh Yusup "setiap orang dengan segala keunikkan dan perbedaannya memiliki jenis kebutuhan yang dapat sama atau berbeda, juga dalam hal kebutuhan akan informasi." (Yusup 2010, 5)

Ruang alternatif seni merupakan ruang temu bagi para seniman untuk saling bertukar informasi dan berbagi pengalaman. Maka hal yang tepat apabila ruang alternatif juga memiliki perpustakaan ataupun menjadi pusat informasi bagi seniman, karena dengan begitu seniman akan lebih mudah mencari informasi dan akan lebih memperkaya pikirannya dengan informasi yang akan menunjang visualisasi karya seniman.

Ciri khas yang perlu diketahui mengenai perpustakaan khusus menurut Yusup (2010) ialah informasinya khusus dan terbatas, mendalam dan mutakhir. Terbatas dalam artian jenis subyek yang dimiliki perpustakaan khusus memiliki jumlah tidak seluas perpustakaan umum karena memang 
jenis subyek yang dimiliki mengikuti jenis instansi yang menaungi perpustakaan khusus tersebut. Begitu pula dengan jenis subyek yang terbatas dalam perpustakaan ruang alternatif, subyek yang muncul lebih kurang mengenai seni ataupun hal terkait seperti kebudayaan ataupun sastra. Karena jenis subyek yang terbatas melatarbelakangi informasi yang disediakan perpustakaan ruang alternatif seni menjadi lebih mendalam. Informasi yang ditawarkan perpustakaan ruang alternatif seni yang tergolong perpustakaan khusus juga lebih mutakhir karena harus mendukung kemajuan instansi dan pegawai dalam memenuhi kebutuhan informasi demi memajukan instansi terkait.

Mengenai perilaku pencarian informasi yang lebih sering dikenal dengan information seeking behavior menurut Wilson ia memberikan definisi mengenai perilaku pencarian informasi yang bertujuan untuk mencari informasi yang dibutuhkan. Definisi perilaku pencarian informasi juga dikemukakan Yusup (2010) sebagai suatu kegiatan atau aktivitas dari individu dalam mencari informasi yang dibutuhkan atau diinginkan dengan suatu tujuan tertentu.

Dalam mencari informasi individu akan melakukan interaksi dengan menggunakan media tekstual seperti buku, majalah, jurnal ilmiah, koran atau perpustakaan dan juga melalui media yang berbasis komputer seperti internet.

Pencarian informasi dari tiap orang memiliki kebiasaan yang berbeda, bahkan lebih lanjut Leckie (2005) menjelaskan lebih rinci mengenai pencarian informasi professional. Ia menjelaskan mengenai pencarian informasi dari tiap orang yang memiliki profesi dipengaruhi beberapa hal yang dibagi menjadi beberapa bagian, dan model pencarian informasi professional Leckie digambarkan melalui ilustrasi gambar dibawah ini:

\section{Bagan 1. Model PencarianInformasi Profesional Leckie}

THE LIBRARY QUARTERLY

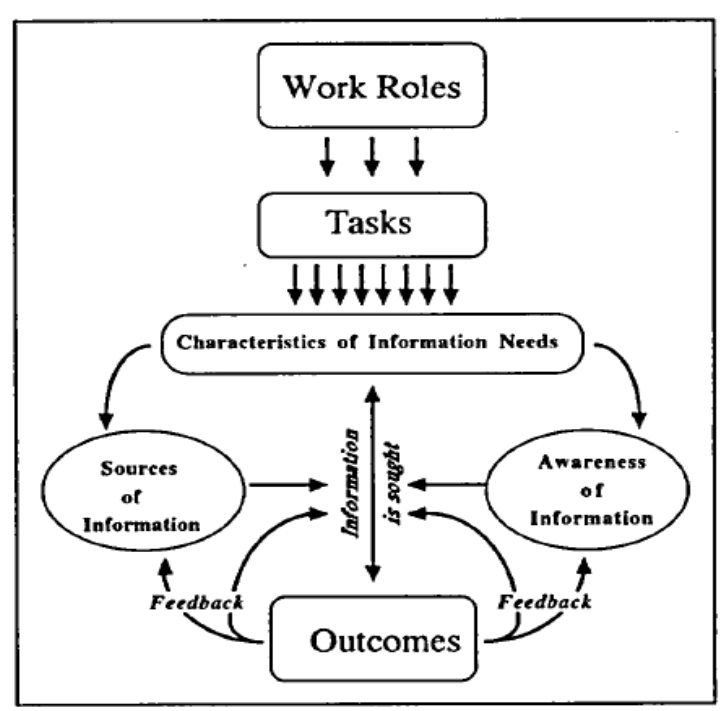

\section{METODE}

Metode dalam penelitian ini adalah kualitatif dengan pendekatan studi kasus. studi kasus digunakan utuk menguji dan atau memperhalus suatu teori (Yin, 1996). Penulis memilih studi kasus sebagai metode dalam penelitian dipengaruhi oleh beberapa hal, salah satunya subyek yang diangkat dalam penelitian ini memiliki keunikan sebagai kelompok profesi yang dinilai nyentrik, berani tampil beda dan kreatif bagi para khalayak umum. Penulis akan langsung berhubungan dengan seniman dilapangan karena seperti pendapat dari Yin (2002) kekuatan dari penelitian studi kasus adalah kemampuannya untuk berhubungan langsung dengan berbagai jenis bukti dokumen, peralatan, wawancara dan observasi. Metode ini dipilih karena dengan metode studi kasus peneliti dapat melakukan pendekatan langsung dengan informan.

Dalam penelitian ini sumber data terdiri berdasarkan sumber data primer dan sekunder. Sumber data primer adalah hasil dari wawancara dan observasi dari para informan yang terlibat secara langsung maupun tidak langsung. Para informan tersebut diantaranya:

1. Pemilik dan Penanggung Jawab s14

2. Pustakawan Perpustakaan s14

3. Seniman di s14

Sedangkan sumber data sekunder berasal dari literature tercetak ataupun digital dari berbagai media dan pengumpulan dokumentasi 
yang berkaitan dengan permasalahan dalam penelitian. Untuk teknik pengumpulan data melalui observasi, wawancara dan studi pustaka.

Analisis data kualitatif adalah upaya yang dilakukan dengan bekerja dengan data, mengorganisasikan data, menyaring data satuan agar dapat dihubungkan dalam penelitian, mengsintesiskannya, mencari dan menemukan pola, menemukan apa yang penting dan apa yang dipelajari, dan memutuskan apa yang dapat diceritakan (Yin 1996).

Untuk menganalisis nya maka penulis menggunakan tahapan reduksi data, penyajian data dan verifikasi yang hasilnya dapat dikumpulkan menjadi sebuah kesimpulan. Tahap akhir dalam pemeriksaan keabsahan data melalui triangulasi penyidik.

\section{Hasil Penelitian}

Sesuai dengan judul dari penelitian ini yaitu Pola Pencarian Informas Seniman di Ruang Alternatif Seni s.14, maka output nya adalah hasil penelitian membentuk sebuah pola yang di sebut Pola Pencarian Informasiseniman. Sebelum itu penulis terlebih dahulu akan menjabarkan pembahasan dari hasil penelitian.

Berbagai profesi memiliki tugas dan peran tersendiri tiap orangnya. Termasuk juga seniman yang menjadi bagian dari salah satu profesi favorite di Indonesia terutama Bandung. Hal ini terlihat dari jumlah lulusan SMA (Sekolah Menengah Atas) yang melanjutkan pendidikan ke tingkat selanjutnya dengan prodi seni rupa dan design di beberapa perguruan tinggi di Bandung terus mengingkat. Menurut data statistik perbandingan daya tampung dengan jumlah peminat berbanding terbalik. Pada tahun 2010 yang mendaftarkan diri berjumlah 4000 orang namun daya tampung yang dapat diterima ITB hanya 125 orang.

Dengan harapan memberikan gambaran ideal mengenai pencarian informasi seniman, penulis melibatkan beberapa pakar yang aktif di bidang seniman dan kesenimanan. Dengan merekonstruksi apa saja yang terjadi di lapangan mengenai pencarian informasi seniman di ruang alternatif seni s.14, para tokoh yang menjadi bagian dari triangulasi data dalam penelitian ini akan memberikan pendapat. Penulis akan membahasnya dalam beberapa point yang terkait dengan penelitian, berikut tiga point utama dalam penelitian ini:

a. Perencanaan, merupakan bagian dari proses pencarian informasi yang dimana dalam penelitian ini seniman mencari informasi sesuai dengan tugas dan peran dalam pekerjaan namun terhambat dengan beberapa sumber yang memilih satu media sebagai alat mencari informasi yaitu internet.

\section{Tugas dan Peran dalam Pekerjaan}

Berdasarkan pemaparan informan yang dimana mereka adalah seniman, seniman telah menyadari peran dalam lingkungan dan pekerjaan serta pemenuhan tugas sebagai salah satu kewajiban. Peran serta tugas dalam pekerjaan yang diidentifikasi dari seniman diatas menghasilkan bahwa tiap individu yang tergabung di ruang alternatif s.14 memiliki peran serta tugas sebagai berikut :

\section{Peran Tugas}

Seniman Menvisualisasikan karya

Dosen Menambah wawasan mengenai ilmu terkait untuk mengajar

\begin{tabular}{|ll}
\hline Wiraswasta & $\begin{array}{l}\text { Promosi dalam pemasaran } \\
\text { karya yang akan dijual }\end{array}$ \\
\hline Freelance & $\begin{array}{l}\text { Membuat artikel dan } \\
\text { liputan menurut } \\
\text { pengamatan freelancer }\end{array}$
\end{tabular}

Tabel 1. Identifikasi Peran dan Tugas Seniman s.14

\section{Penyeleksian Informasi}

Dalam point ini penulis mengidentifikasi berdasarkan hasil wawancara dan pengamatan langsung di lapangan bahwa seorang seniman yang akan mencari informasi mulai mengidentifikasi topik yang akan dicari sehingga ketidakpastian diawal mulai menciptakan rasa optimisme dan kesiapan dalam memulai informasi. Seniman di ruang alternatif $\mathrm{s} .14$ telah mampu mengerucutkan informasi yang akan dicari berdasarkan tingkat kebutuhan serta waktu dari kegunaan informasi tersebut. 
b. Prosedur, merupakan standar pemilihan informasi dari seniman mengenai pemilihan informasi, media yang digunakan sebagai alat pencarian informasi hingga eksekusi yang dilakukan seniman dalam mencari informasi. Tahapan selanjutnya dalam pencarian informasi seniman s.14 masuk ke dalam tahap prosedur, dimana prosedur merupakan alur ataupun step by step yang dilakukan seniman dalam mencari informasi. Tahapan prosedur penulis labeling dalam pencarian informasi seniman s.14 dilatarbelakangi berdasarkan gejala yang penulis tangkap di lapangan melalui pengamatan langsung dengan dukungan wawancara bersama informan yang terkait di s.14.

Seniman tidak memiliki prosedur yang khusus dalam pencarian informasi, namun mereka telah memiliki ketetapan yang secara tidak langsung dilakukan oleh semua seniman terutama di ruang alternatif seni $\mathrm{s} .14$ berikut ketetapannya:

\section{Kemudahan dalam Pencarian Informasi}

Setiap individu dalam mencari informasi tentu akan mengejar kemudahan dalam mengakses informasi. Begitu pula dengan seniman ruang alternatif seni s.14 di tengah era informasi ini mereka mengharapkan sumber informasi yang mudah di akses dan di dapatkan, sehingga mobilitas serta aktifitas harian tidak akan terganggu.

Untuk sementara waktu ini internet sangat mendominasi kemudahan seniman dalam mencari dan mendapatkan informasi.

\section{Kecepatan}

Ketika aktivitas serta mobilitas keseharian sedang tinggi dan membutuhkan perhatian yang ekstra, pencarian informasi harus dilakukan seefisien mungkin sehingga tidak menggangu aktivitas harian.

Pemenuhan kebutuhan informasi untuk mendukung pekerjaan harus diimbangi dengan kecepatan dalam mendapatkan informasi agar deadline ataupun tugas dalam pekerjaan dapat diselesaikan sesegera mungkin.

\section{Mendukung Visualisasi Karya}

Aktivitas utama sebagai seniman yang membutuhkan referensi untuk membantu menvisualisasikan karya. Hasil wawancara serta pengamatan langsung dengan seniman dalam tahapan prosedur pencarian informasi, seniman akan menyesuaikan informasi demi menunjang visualisasi karya mereka dan juga untuk mendukung pekerjaan mereka lainnya.

c. Sumber informasi,Terasa aneh jika kita membahas mengenai pencarian informasi namun tidak membahas sumber informasinya. Karena setiap pencarian informasi pasti memiliki sumber yang akan diolah oleh pola piker masing - masing sehingga menghasilkan informasi untuk mendukung pekerjaan serta peran kita dalam lingkungan. Beragam media yang tersedia saat ini seniman memilih sumber informasi yang mengutamakan kemudahan dan kecepatan dalam mengakses.

Jawaban yang dihantarkan oleh para informan di dominasi oleh sumber informasi melalui internet. Meskipun ada informan yang mengatakan bahwa melalui diskusi langsung pendapat ataupun hasil karya seniman lebih cepat mendapatkan respon atas aplikasi informasi yang diserap.

Dari pencarian informasi yang telah dilakukan seniman diatas menghasilkan sebuah informasi yang digunakan oleh seniman. Hasil yang di maksud mendukung visualisasi karya serta memperkaya seniman dalam pengetahuan yang akan dituangkan juga dalam bentuk tulisan. Namun jika pencarian informasi yang dilakukan belum sesuai dengan apa yang telah diharapkan oleh seniman, hal tersebut bisa saja terjadi apabila hambatan ditemui ketika melakukan pencarian informasi.

Setelah merangkai pencarian informasi yang terjadi di lapangan, penulis mencoba merekonstruksinya dalam bentuk sebuah pola. Berikut gambaran mengenai pencarian informasi seniman ruang alternatif seni s.14 


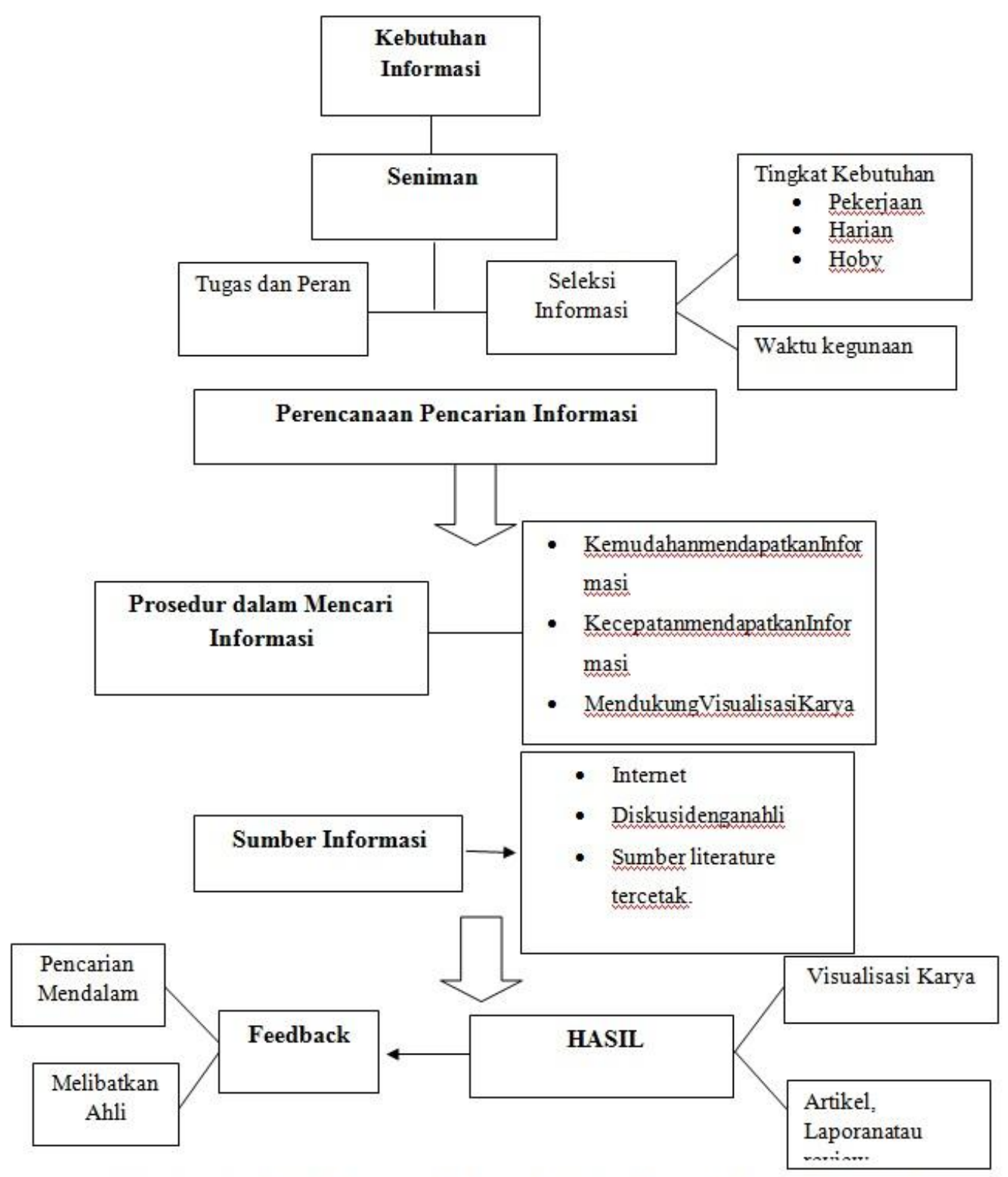

Gambar 2 Pola Pencarian InformasiSeniman Ruang Alternatif Seni s.14

\section{Simpulan}

Berdasarkan data di lapangan yang didapatkan melalui wawancara serta pengamatan langsung penulis menarik kesimpulan dalam penellitian ini ke dalam beberapa point yang akan dijabarkan berikut ini:

1. Perencanaan pencarian informasi seniman yang dilakukan oleh seniman di ruang alternatif seni s.14 dilakukan berdasarkan beberapa point di bawah ini, yaitu a) Seniman dalam mengidentifikasi kebutuhan informasi melalui tugas serta peran dalam lingkungan. Satu orang seniman yang konsen di dalam dunia seni rupa memiliki tugas serta peran yang berbeda satu sama lain.

Hal itu menjadi alasan mengapa kebutuhan informasi setiap orang berbeda - beda. Berdasarkan peran dan tugas itu seniman memiliki bekal untuk melakukan pencarian informasi. Tugas sebagai seniman 
menvisualisasi karya ke dalam sebuah bentuk. Tugas seorang pendidik (dosen) memberikan bimbingan terkait dengan perkuliahan serta pencerahan mengenai karya seniman. Secara umum peran yang paling menonjol dalam penelitian ini adalah peran sebagai seorang seniman yang menvisualisasi karya dan menjadi referensi bagi seniman lain dalam memandang sebuah karya.

b) Penyeleksian informasi dilakukan untuk berdasarkan tingkat kebutuhan dan waktu penggunaan dari informasi tersebut. Tingkat kebutuhan ditandai ke dalam beberapa point, hal itu berkaitan dengan informasi berkaitan dengan pekerjaan setelah itu informasi yang menyangkut kehidupan sehari - hari dan informasi yang berkaitan dengan hobby. Setelah mengetahui tingkat informasi yang dimiliki penyeleksian selanjutnya mengenai waktu. Waktu di identifikasi berdasarkan kapan digunakannya informasi tersebut.

2. Prosedur pencarian informasi seniman di ruang alternatif seni s.14 terbagi menjadi tiga hal dalam penelitian ini yaitu kemudahan dalam mendapatkan informasi menjadi keutamaan pencarian informasi seniman. Setelah itu kecepatan dalam mendapatkan informasi tersebut. Terakhir adalah informasi harus berkaitan dengan visualisasi karya dari seniman.

3. Sumber literature yang digunakan oleh seniman ruang alternatif seni s.14 seniman lebih memanfaatkan internet sebagai sumber literature utama yang diikuti dengan pencarian melalui artikel, buku, katalog dan majalah yang didapatkan melalui toko buku dan perpustakaan. Hasil dari pencarian informasi seniman dihantarkan ke dalam dua bentuk yaitu visualisasi karya seni rupa dalam beragam media baik itu konvensional atau kontemporari. Kedua hasil disajikan dalam bentuk laporan, review, makalah, artikel serta buku. Feedback adalah tingkat lanjutan dari seniman apabila beberapa hal yang telah dilakukan dalam mendapatkan informasi tidak sesuai dengan yang diharapkan, seniman akan merajuk informasi kepada pakar atau orang yang ahli di bidang tersebut agar bisa melakukan pencarian yang mendalam.

\section{DAFTAR PUSTAKA}

Aini, Mutri Batul. 2009. "Studi Kasus Peran Perpustakaan Khusus dalam Penerapan Knowledge" diakses 31 Mei 2009 http://lontar.ui.ac.id/file?file=digital/12683 3-RB13M440p-Peran\%20perpustakaanLiteratur.pdf

Andriani, Juznia. 2011. "Studi kasus di Pusat Perpustakaan dan Penyebaran Teknologi Pertanian, Bogor." Jurnal Perpustakaan Pertanian Vol. 20, Nomor 2, 2011. Diakses 25 Maret 2013.

http://pustaka.litbang.deptan.go.id/publikasi/ pp202115.pdf

Fisher, Karen et all. 2005. Theories of Information Behaviour. United State:ASIST Monograph Series

Galeri S.14. 2011. Profil Galeri S.14 Bandung. diakses $20 \quad$ Desember 2013. http://ruangdepan.blogspot.com

Iskandar, Popo. 2000. Alam Pikiran Seniman.Bandung: Yayasan Popo Iskandar

Kompas..2013. Para Kandidat Calon Gubernur Jawa Barat. di akses pada tanggal 25 Februari 2013. http://lipsus.kompas.com/jabarsatu/kandidat

Leckie, Gloria J. 2005. "General Model of the Information Seeking of Professionals." Dalam Theories of Information Behaviour, Editor Karen E.Fisher, 158-163. United States: ASIST Monograph Series

Moleong, Luxe. 2000. Metode Penelitian Kualitatif. Bandung: Rosdakarya

Mulyana, Deddy. 2008. Metode Penelitian Kualitatif: Paradigma Baru Ilmu Komunikasi dan Ilmu Sosial Lainnya. Bandung: Remaja Rosdakarya

Supangkat, Jim. 2001. Dua Seni Rupa: sepilihan tulisan samemto yuliman oleh Editor Asikin Hasan, vii.Jakarta:Yayasan Kalam

Wilson, T.D. 1981. "Evolution in Information Behaviour Modeling: Wilson's Model." Dalam Theories of Information Behaviour, Editor Karen E.Fisher, 31-36. United States: ASIST Monograph Series 
Yin, Robert K. 1996. Studi Kasus Desain \& Metode. Jakarta: RajaGrafindo Persada

Yusup, Pawit M, and Priyo Subekti. 2010.Teori \& Praktik Penelusuran Informasi: information retrieval.Bandung: Prenada Media

Yusup, Pawit M. 2012. Manajemen Ilmu Pengetahuan.Bandung:Rajawal 